\title{
REVERSED JENSEN TYPE INTEGRAL INEQUALITIES FOR MONOTONE FUNCTIONS
}

\author{
P. J. Bushell AND A. CARBERY
}

\begin{abstract}
Reversed Jensen type integral inequalities for monotone functions are deduced from a more general inequality. Special cases are of interest in the study of Volterra integral operators.
\end{abstract}

Mathematics subject classification (2000): 26D15, 45D05.

Key words and phrases: Integral inequalities, Volterra integral operators.

\section{REFERENCES}

[1] S. BARZA, J. PEČARIĆ AND L. E. PERSSON,, Reversed Hölder type inequalities for monotone functions of several variables, Math. Nachr. 186 (1997), 67-80.

[2] G. BennetT, Factorising the classical inequalities, Mem. Amer. Math. Soc. 120 (1996).

[3] J. BERGH, A converse inequality of Hölder type,, Math. Z. 215 (1994), 205-208.

[4] Yu. V. EgOROV, On an integral inequality, Operator Theory: Advances and Applications, to appear.

[5] H. Heinig AND L. Maligranda, Weighted inequalities for monotone and concave functions, Studia Math. 116 (2) (1995), 133-165.

[6] A. A. JAGERS, An integral inequality of Bushell and Okrasinski, to appear.

[7] J. PeČARIĆ, I. Perić AND L. E. Persson, Integral inequalities for monotone functions, J. Math. Anal. and Appl. 215 (1997), 235-251.

[8] W. WALTER AND V. WeCKESSER, An integral inequality of convolution type, Aequationes Math. 46 (1993), 212-219. 